\section{Still room for HUGO?}

\section{Washington \& London}

IF headlines were what the human genome project was after, 1991 would have been an unqualified success. US genome researcher Craig Venter nearly caused an international incident by filing a surprise patent application for 350 unidentified human gene fragments. Then UK government researchers shocked their US counterparts by trying to charge industry for looking at their genome data.

It was not quite open warfare, but it was twelve months marred by misunderstandings and culture clashes - just the sort of thing, in fact, that genetic pioneer Victor McKusick hoped to avoid when he created the Human Genome Organisation (HUGO) in 1988 to serve as a coordinating body for international genome research. So, as researchers on both sides of the Atlantic crossed signals and missed cues, where was HUGO?

Trying to stay alive, mostly. Three years after its inception, HUGO is "still incipient" in the words of David Galas, the US Department of Energy genome chief. For one thing, it is badly in need of cash. When James Wyngaarden resigned as its director last August, HUGO courted Rockefeller University microbiologist Norman Zinder as a replacement until it realized it could not afford to pay him. Now the position will "remain unfilled indefinitely", says Charles Cantor, vice president of HUGO. "Our resources are really limited."

Nearly all of HUGO's US funding comes from a four-year, \$1-million grant from the Howard Hughes Foundation. In Europe, two British charities, the Wellcome Trust and the Imperial Cancer Research Fund (whose director-general, Sir Walter Bodmer, is HUGO's president) have between them picked up a similar-sized bill.

Many of the problems, Cantor says, stem from early mistakes in HUGO's creation. HUGO is chartered in Switzerland, a move that was supposed to give it tax advantages; instead it turned out to put some strict restrictions on the organization's operations. Swiss law makes it difficult to change articles of federation without long legal processes. When HUGO had to revamp its organization to keep up with the shifting needs of the genome project, the changes turned out to be, as Cantor puts it, "painful and expensive - with a lot of lawyer's fees".

HUGO now has offices in London, Washington, Osaka and Moscow (which opened in July), but only the UK and US offices are incorporated as nonprofit companies, which in the United States entitles HUGO to receive tax-free funds. In Japan, an organization must have a large amount of capital to gain tax-exempt status. So even though HUGO has staffed its Japanese office, it has been caught in a Catch-
22: It does not have enough seed money to win nonprofit status, yet it is difficult to solicit money in Japan until it has that designation.

Even where it has acquired tax-exempt status HUGO has run into problems. A registered nonprofit organization in the United States must by law receive its funding from more than one source, but only a few tiny grants have saved HUGO from being reliant solely on the Hughes Foundation. And because it has no real offices in the United States (except an apartment in Bethesda, Maryland, that Hughes lets it use), it does not have the accounting pro-

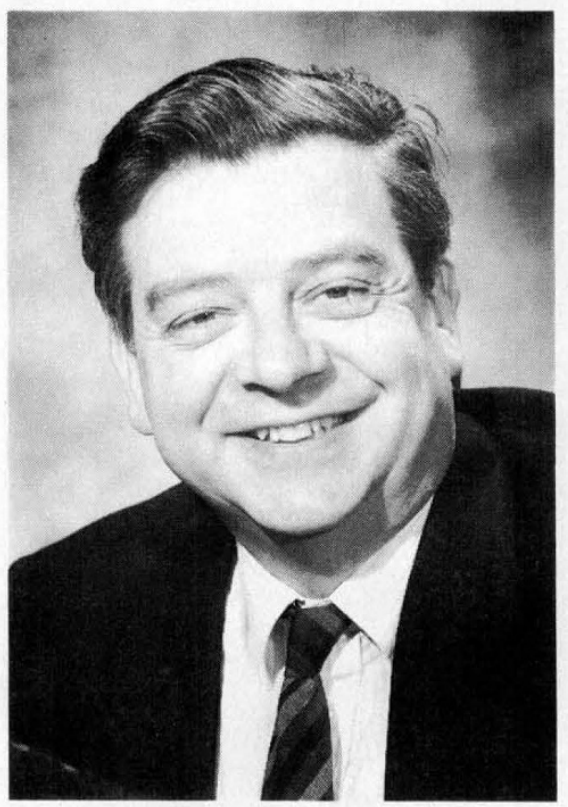

Bodmer's HUGO is still finding its place.

cedures and infrastructure necessary to win government grants. Moving under the wing of Johns Hopkins University, something it hopes to do early this year, may finally give HUGO access to the government funding pool.

The Moscow office had barely opened its doors when August's attempted coup threw its future into question. First, Nikolay Laverov, the deputy prime minister who had pledged funds from the Soviet genome project to support HUGO's Moscow venture, was removed from office in the purge that followed the coup's failure. And now that the central Soviet government has collapsed completely, the HUGO office's long-term future is uncertain. Aleksander Bayev, the senior genome project official in Moscow, expects to get money for genome research (and for the HUGO office) from the Russian government, but the 1992 budget has not yet been approved by the Russian parliament.

Despite the difficulties, the Moscow office has made some progress in its two main tasks: to coordinate data collection for the Soviet project, and to improve communications between Soviet genome researchers and their counterparts in the West (although engineers are still working on an on-line electronic link to the German Cancer Centre in Heidelberg, to give Soviet researchers access to the leading gene databases).

While HUGO has been trying to get up to speed, the genome project has been growing up largely alone - pains and all. In the recent imbroglio over cDNA patenting, for example, the news that Venter had filed a patent for 337 unidentified human gene fragments first came out together with a flood of controversy - at a HUGO-sponsored workshop during the 11 th Human Gene Mapping Workshop in London in August. Some argued that the utter surprise of the UK participants when they learned of the patent application indicated that HUGO has not been doing its job; it was, after all, supposed to be the communications channel for international issues in the genome project. Unilateral decisions about issues as big as gene patenting rarely go over well when they are announced after the fact.

But Cantor points out that the news did nevertheless break at a meeting sponsored by HUGO, not informally or at some later conference. In that sense, although HUGO's efforts at opening communications did not prevent a tumult, they did bring up the issue before things got too far out of hand. Since the meeting, HUGO has set up a committee to study the problem of international data access and make specific recommendations to avoid the problem in the future. Cantor says that he expects that the committee will report in the next several weeks.

Cantor believes that HUGO's darkest days are behind it. Although HUGO was originally set up on what he calls an "elitist academic model" (each of the 400 researchers who have joined HUGO to date have had to be nominated by five existing members, endure a pre-screening process, and be approved by the entire membership), new members will have to get only two nominations and no vote will be necessary. Cantor hopes this will double or triple the membership.

Nevertheless, reinventing HUGO will take more than new rules; for one thing, there is still widespread confusion about just what it is supposed to do. This is partly due to HUGO's changing charter. Three years ago it was hoping to be a great mediator, setting such policies as collaboration and data-trading practices. That lofty aim soon fell by the wayside when it became apparent that, without money, HUGO was not going to be a significant player in genome sweepstakes. Now, Cantor says, "HUGO is primarily a facilitator and a coordinator." HUGO will bring the researchers together, Cantor explains, and then they will set their own policies.

In the coming year, HUGO intends to 
take the initiative in organizing the input of data into the main gene-mapping database - the Genome Database (GDB) run from Johns Hopkins. Until now, the "consensus' mapping data in GDB have been agreed and entered into the database, at the hectic Human Gene Mapping Workshops, held every couple of years. But the volume of data is becoming too large to be handled at a single meeting, and consensus maps for each chromosome will in future be updated at HUGO-sponsored Single Chromosome Workshops, 18 of which are planned for 1992. Once a year, representatives of the teams working on each chromosome will get together to discuss their common problems.

Unfortunately, when HUGO luminaries including Cantor, Bodmer and McKusick outlined the plan to the genome community at the London Human Gene Mapping Workshop in August, many researchers reacted angrily. HUGO offi-

cials in London play down the difficulty as a breakdown in communication: many people assumed that the new meetings would exclude most 'grass roots' genome researchers. In fact, the large biennial meetings will continue (without the timeconsuming debates over consensus mapping data, and renamed as Human Genome Mapping Workshops), providing an opportunity for the diverse genome community to get together. This public relations blunder was an inauspicious start to HUGO's new role in gene mapping. The success of the HUGO-sponsored meetings is seen as a litmus test of the organization's ability ever to have an effect on the international coordination of the genome project, and Cantor is depending on a more polished performance in 1992. "The success of HUGO depends on these meetings," he says. "They have to work." Christopher Anderson \& Peter Aldhous

\section{BRITISH RESEARCH FUNDING}

\section{Universities face changes}

\section{London}

BRITISH science leaves 1991 in a more cheerful state than it entered. A year ago, the UK research councils were busy counting pennies, realizing that their funding from government would not keep pace with inflation. The largest of the five, the Science and Engineering Research Council (SERC), which had banked on a much larger budget, was forced to review its whole programme and award only about half the new research grants it had planned. But the research councils' allocations for 1992-93, announced just before Christmas (see table), should allow for a small amount of growth. Even the Agricultural and Food Research Council, which declared a financial emergency in October after the collapse of the UK property market wrecked its plans to sell $£ 7$ million worth of empty laboratory buildings, has been given a special $£ 5.7$ million 'loan' to ease its cash flow.

With a general election due by the summer, the government's increased generosity is not so surprising. But Britain's researchers should not expect an uneventful 1992, which will see changes in the funding of university research that will dwarf the fallout from last year's research council funding hiccup. The Universities Funding Council (UFC), which distributes nearly $£ 700$ million a year of public money to support research (more than twice the amount spent in the universities by the research councils), plans this year to revamp its mechanism for dividing its research budget among the universities. The result will be that money becomes concentrated in the few UK universities that have an outstanding reputation for research; those that can boast little in the

way of research excellence may find themselves suddenly short of funds.

At present, some 40 per cent of the UFC's research funding is distributed simply according to student numbers - universities with more students get more money, irrespective of the quality of the research in their departments. The UFC has been gradually moving towards funding criteria that take a greater stock of the quality of university research, but the government's plans to abolish the distinction between universities and polytechnics in time for the 1993 student entry have forced more rapid progress.

\section{2-93 budgets for the UK research councils (Emillion):}

Agricultural and Food 107 Economic and Social $\quad 45.1$ Medical

Natural Environment 45.1
227.6 129.7 Science and Engineering 520.8 Figures in brackets give the percentage increase in cash terms from 1991-92 excluding the $£ 47.7$ million transferred to the research councils from the UFC.

If the new funding councils that are to fund both the universities and the polytechnics simply adopted the UFC's old funding mechanism, the result would be a sudden redirection of research funds away from the universities and into the polytechnics, which have students galore. (The UFC's counterpart, the Polytechnics and Colleges Funding Council, now spends only several tens of millions of pounds each year on research.) As the government has said that it is not prepared to see this happen, the distribution of research money according to student numbers must end, and to smooth the transition, the UFC is moving swiftly to bring this about.

UFC officials cannot yet say exactly how the council's 1992-93 research budget will be divided among the universities - the final decision has not yet been taken. But they are confident that the largest factor in deciding each university's allocation will be the UFC's assessment of the quality of research in British university departments, a formidable exercise in peer review that was last attempted in 1989 , and will be repeated this year.

The concentration of funding in Britain's leading research universities will be compounded this year by the transfer of some $£ 50$ million of UFC money to the research councils, which already direct the majority of their research grants to a select few institutions. (Ten British universities - Birmingham, Cambridge, Edinburgh, Glasgow, Imperial College London, Leeds, Manchester, Oxford, Southampton and University College London - win more than half SERC's university research grants.) This transfer is designed to cover some of the indirect costs of university projects funded by the research councils, and by 1994-95 will be followed by a further $£ 100$ million a year that now comes under UFC's budget.

For a fortunate few universities, the changes beginning in 1992 will be welcome. But those with a patchier research record can expect a painful transition. Squeezed from above by the emerging university 'super league', and from below by the polytechnics that wish to claim a slice of the research pie, several university vice-chancellors will face a difficult dilemma over the next few years: whether to divide their shrinking research budget evenly among their departments, or to follow the national trend and penalize weak departments to ensure that research in the strongest is not undermined. The former might minimize faculty protest, but would carry a long-term penalty - any university that takes research money from its best departments to subsidize the rest would soon slip down the UFC's table of research excellence and receive still less money the next time around.

The present turn of events should bring a wry smile to the face of Sir David Phillips, chairman of the Advisory Board for the Research Councils (ABRC). In 1987, the ABRC published its Strategy for the Science Base, which proposed that only the best research universities should support a full research programme and said that many UK universities should become teaching-only institutions. After howls of protest from the universities, the government dropped its initial support for the idea. But with the present changes in university funding leading in the much same direction, the ABRC's follow-up to its 1987 document, due to be published in April this year, should make interesting reading.
Peter Aldhous 